\section{AESTHETICS OF KHLONG IN THAI POETRY: CONVENTION AND CREATIVITY $^{1}$}

\section{Weerawat Intaraporn ${ }^{2}$}

\begin{abstract}
This paper aims to illustrate the beauty of khlong (Thai poetry) creatively written and transmitted from the past to the present through a study of the preservation and creation of aesthetics in relation to euphony, and diction, as well as the imitation of words used by previous poets with new meaning in Thai poetry. From the study, it is found that Thai poets of each era have both followed and adapted the traditional style of composition. In terms of euphony, poets from the past to the present put an emphasis on tones at the end of each line, play on different tone levels, and use internal rhymes as seen in both alliteration and assonance. As for diction, puns, either homophones or homonyms and repeated words are employed. Regarding word formation, even though it is obviously seen that poets
\end{abstract}

\footnotetext{
${ }^{1}$ This research paper is part of a doctoral dissertation on 'Aesthetics of khlong in Thai poetry: Literary Creation from the Nature of Thai Language,' Department of Thai, Faculty of Arts, Chulalongkorn University, 2005. The researcher would like to express his gratitude to his dissertation advisor, Associate Professor Cholada Ruengruglikit, Ph.D. for her useful advice, without which this research would not have been possible.

${ }^{2}$ Ph.D. Candidate in Thai, Department of Thai, Faculty of Arts, Chulalongkorn University, Thailand.
}

have imitated the same words employed by poets of previous generations, they have also adapted and developed them to suit the individuality of each poet for the unique aesthetics of both diction and concept. It can be said that the creation of melodious and witty khlong is congruent with the nature of the Thai language since khlong is Thai in its origin and this in itself enhances the effectiveness of Thai poets in making use of the dominant characteristics of the Thai language in the composition of their poetic works from the past to the present.

\section{Introduction}

Among all types of Thai verse, khlong has long been given significance by poets throughout the history of Thai literature. It is presumed that khlong originated at almost the same time as rai, another classical type of Thai verse. (Watchari Ramayanun, 1995: 78). The evidence can be found in a work of Thai literature written in the central part of the country, Lilit Ongkan Chang Nam, composed around the beginning of the Ayudhaya period in the reign of King Ramathipbodi I. A lot of Thai literature experts such as Chit Phummisak, Phraya Uppakit Sinlapasan, Prakhong Nimmanhaeminda and Cholada Ruengruglikit concur that khlong is a pattern of verse shared by Thai people and the tribe of 'Tai,' as testified by the fact that khlong or verses whose patterns resemble that of khlong have been found in the literary works of Thai people and of many groups of the 'Tai' tribe. The fact that the original pattern of khlong was shared between Thai people and the tribe of 'Tai,' has enabled poets to create their khlong, as seen in a lot of masterpieces of Thai literature, by making use of the nature of the Thai language. Even though the popularity of composing a long story in khlong nowadays seems to be in 
decline, a lot of modern Thai poets still see its value and choose to compose their poems in khlong.

It can be clearly seen from all the verses in khlong which have been composed by poets from the past up to now that poets of each era not only adopt the concept of creating in accordance with the aesthetics of the poets of previous generations but also adapt previous forms for literary novelty and to express their individuality. Since khlong is significant in terms of both literary conventions and the style which has been used in composing Thai literature by poets of all eras, it is appropriate that the study of the literary conventions and creativity of khlong, created by the use of the Thai language, should be researched.

This study aims to trace literary conventions and creative aesthetics of the Thai khlong from the past to the present day in order to illustrate the beauty of khlong.

In the study, the researcher would like to prove that in composing khlong, poets of each era have not only been endowed with the process of creativity from poets of previous generations in terms of euphony, diction, and the imitation of words used by previous poets with new meaning but developed these to suit their own purposes as well.

From various masterpieces of Thai verse in khlong form that have been collected, written from the beginning of the Ayudhaya period to the present day, Rattanakosin era, the researcher has found the following:

\section{Convention and Creative Aesthetics of Khlong in Regard to Euphony}

In composing Thai literature, euphony is considered the most important element. As noted by Prince Narathipphongpraphan, literature is the art performed by diction, especially in verse, and the words must be mellifluous when read aloud. (Prince Narathipphongpraphan. 1975: 108) Therefore, euphony is important in writing khlong, specifically in the early period of the composition of khlong. Due to the fact that khlong was originally written to be recited, to appreciate it was duly based on the sounds, as seen in an example of Thai literature of the early Ayudhaya period, Lilit Phra Lo, ' สรวลเสียงขับอ่านอ้าง ใดปาน ฟัง เสนาะใดปูน เปรียบได้ - A recital of khlong is so full of elation and impressively melodious that no sound on earth can compare. (Wannakam Samai Ayudhaya Vol.I, 1997: 387) This paper will illustrate the conventions and creative aesthetics of euphony in two respects: playing on different tone levels and internal rhymes.

\section{Playing on Different Tone Levels}

The fact that khlong has a requirement that determines the specific place of tones, which is the dominant feature of the Thai language, in its composition apart from such general rules for poetic composition in Thai as the number of words, hemistich and rhymes makes its prosodic pattern distinct from other types of Thai poetry. However, tones are not used for the sake of a prosodic pattern, but they can help create euphonious articulation due to their musical qualities. Poets of each era have preserved the use of tones in creating euphony in two ways: 


\section{a) Requirement of Tones at the End of Each Hemistich or Each Full Line}

In composing all types of khlong, even though there is no specific rule to specify the exact tone at the end of a stanza, poets select only mid and rising tones to make khlong melodious. This charac-teristic can be found in both Khlongsidun and Khlongsisuphap written since the early period of khlong composition up until now. A good example can be seen in a Khlongsisuphap written at the beginning of the Ayudhaya period, Lilit Phra Lo, whose stanza ends with a rising tone as seen in 'sŏng' below.

făn hěn phrá phûen thái sǒng nâep non naem sŏng sǒng sĩ sòt kon tràkong chuan chák pai lái lái

phaeng thong tràp thái

kòt rât lae na sù bân mueang sơng

\section{(Wannakam Samai Ayudhaya} Vol.I, 1997: 405)

Apart from the end of each stanza, the rising tone can be found at the end of a hemistich or full line, which rhymes with the next line, called external rhyme in each stanza. That is, the last word of line one rhyme with the last word of the first hemistich of line two and the last word of the first hemistich of line three.

The employment of the rising tone at the end of the stanza and at the end of a hemistich or full line, which is also an external rhyme, can be found in khlong of all eras. Some poets have used the rising tone in the aforementioned places at a frequent rate in their works; for instance, Supreme Patriarch Prince Paramanuchitchinorot, in his masterpiece, Lilit Taleng Phai, prefers to end each stanza and hemistich and line with the rising tone. $\mathrm{He}$ uses this pattern continuously in many stanzas. The following is a good example to show how he uses rising tones at the end of the stanza and at the rhyming places between the hemistiches of line 1 and line 3.

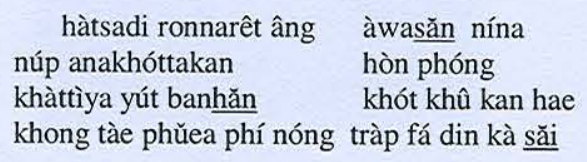

hàtsadi ronnarêt âng àwasăn nína núp anakhóttakan hòn phóng khàttìya yút banhăn khót khû kan hae khong tàe phǔea phí nóng tràp fá din kà săi

(Supreme Patriarch Prince Paramanuchitchinorot, 1987: 85)

The use of the rising tone at the end of a stanza and the position of external rhymes has been practised by modern poets as well. It can be seen in Naowarat Phongphaibun's work where the rising tone is frequently employed. A good illustration is his Khlongsisuphap, titled Chak Ma Chom Mueang:

\begin{tabular}{ll}
\multicolumn{1}{c}{ thewan thân yù fâ } & yù făn \\
rue chàk loi long sawăn & sèk sâng \\
mue manút ní làe ban- & dan ùbàt \\
ngùea yàt là yòt láng & lòló mue sŭang
\end{tabular}

(Naowarat Phongphaibun, 1977: 45)

The researcher thinks that using the rising tone at the end of the stanza helps impart a melodious effect to the khlong since a rising tone is a tone which changes the level of the tone from the central rather low pitch to the lower level and then the level will change from the high pitch to the central rather high or high pitch. (Phathani Chotikkasathian, 2001: 264). Therefore, the employment of the rising tone at the end of a stanza results in a lengthy sound which is suitable for the close. When khlong is recited, it is melodious. Also, the use of the rising tone at the end of hemistiches which is the required position for external rhymes also makes khlong mellifluous due to the contrastive sounds of higher and lower tone levels. It is not surprising that the 
employment of the rising tone is part of the literary heritage up until now.

\section{b) Playing on Different Tone Levels}

Playing on different tone levels refers to the technique of putting close together two words which are composed of the same initial consonants, vowels and consonances but of different tone levels. This results in higher and lower pitches which lend a musical quality to khlong. The use of different tone levels can be created by the repetition of consonants and vowels and the contrastive pitches between higher and lower tone levels. Moreover, tone levels can distinguish the meaning of one word from another. Thus, playing on different tone levels is simultaneously playing on the meaning of the words as well.

Playing on different tone levels can be found in every type of khlong ever written since the beginning of the Ayudhaya period. However, in modern khlong, for the most part, playing on different tone levels is limited to two adjacent tone levels. It has been found that playing on three different tone levels was practised at the beginning of the Ayudhaya period; Cholada Ruengruglikit has mentioned one hemistich in Yaun Phai Khlong Dan which play on three different tone levels. (Cholada Ruengruglikit, 2001: 512). However, this practice is not as popular as playing on two different tone levels.

In the reign of King Naraimaharat, Phrasimahosot made use of the play on three different tone levels in his Khlong Akson Sam Mu. He composed it in the form of โคลงกลบท --Khlongkonlabot which requires that three words with the same spelling but different tone levels be put next to one another in each hemistich. bua bueng tum tùm tûm klang tom sŭng sòng thong than lom lôm lóm malaeng máo mâo mao chǒm chom sâp ru rû rú rim kôm phât mái sai ro

(Wannakam Samai Ayudhaya Vol.II, 1985 : 647)

Khlong Akson Sam $\mathrm{Mu}$ is considered the only entire work which was written in the form of Khlongkonlabot. Later, this requirement became the rule in composing กลอนกลบท --Klonkonlabot. Evidence can be found in Konlabot Siriwibunkit. Written near the end of the Ayudhaya period, this Klonkonlabot was named 'Konlabot tripradap'.

Another aspect that poets take into consideration when they play on different tone levels is the meaning of the words. This is the reason that why playing two different tone levels is more prevalent than playing three different tone levels. It is not easy to put together more than two words which have the same spelling but different tone levels and give a profound meaning which corresponds with the concept of the poem. Even in Phrasimahosot's Khlong Akson Sam $\mathrm{Mu}$, there are some words which are not clear in their meaning. It is found that the content in some hemistiches is not clear but the poet has to compose them in accordance with the requirements of the adjacent different tone levels. This can be seen in a line of this khlong 'ปีนป่าย ทลายทลวงเผา เผ่าเผ้า'--pin pài thàlai thàluang phăo phào phâo. (Wannakam Samai Ayudhaya Vol.II, 1985: 645). This line describes the battle scene in which an enemy burns down a barrack. The poet plays on words with different tone levels: 'phăo' (เผา) 'phào' (เผ่า) 'phâo' (เผ้า). The word 'phăo' means to burn and the word 'phào' which usually means kinship or clan refers to a contingent of soldiers in 
the barrack. However, the word 'phâo', which generally means hair, does not yield a clear meaning since it is by no means congruent with the context of this line. Thus, there were few poets at the beginning of the Rattanakosin period who practised the play on three different tone levels. A good example can be found in Chaophraya Phra Khlang (Hon)'s Lilit Pet Mongkut, which was written in imitation of. Phrasimahosot's Khlong Akson Sam $M u$; however, the poet used this technique in one stanza only. Another literary figure who was influenced by Phrasimahosot's Khlong Akson Sam Mu is Sunthon Phu. In his Khlongnirat Suphan, Sunthon Phu made use of different tones for the sake of onomatopoeia. However, Sunthon Phu did not follow the requirements of Phrasimahosot's Khlong Akson Sam Mu strictly as we can see that Sunthon Phu made use of three or four different tone levels. An example of the employment of three different tone levels can be seen in 'พญาลอ ล่อล้อคลอ' --phaya lo lô ló khlo. (Chiwit Lae Ngan Khong Sunthon Phu, 1987: 314) and of four different tone levels in "ฆ้องหน่อง หนองน่องหน้อง' --khóng nòng nǒng nông nông. (Chiwit Lae Ngan Khong Sunthon Phu, 1987: 314). It is noteworthy that Sunthon Phu also included the high and rising tone marks which were not used by Phrasimahosot. It is surmised that the tone marks which were used in writing in Phrasimahosot's period were only the low and falling tone marks.

The play on different tone levels can be found in some khlong which were composed after the beginning of the Rattanakosin era, for instance, in the reign of King Rama V. Nevertheless, its popularity declined and what can be found later is only the play on two different tone levels. As for modern khlong, it is obvious that poets hardly play on different tones. However, there are some poets who have studied the works of the poets of previous generations and preserved the tradition of playing on different tone levels like Angkhan Kanlayanaphong, Naowarat Phongphaibun and Phaiwarin Khao-ngam The reason for the decrease in popularity might be that modern poets put an emphasis on the concept or message of khlong and playing on different tone levels may make the meaning of khlong unclear or dilute the gist of khlong that poets would like to convey.

\section{Playing on Internal Rhymes}

Internal rhyme is another type of euphony which enhances the musical quality of khlong. It can involve the repetition of vowel or consonant sounds. Internal rhyme is not required like external rhyme which is the repetition of vowel sounds. However, poets like to use internal rhyme to make their khlong more mellifluous. There are two types of internal rhyme that poets use. First, poets may put words which have the same vowel or consonant sounds close together, which is called 'sămphàt chít' (สัมผัสชิด) - neighbouring rhymes as can be seen in 'สองขอยอยศไท้' (sǒng khŏ yo yót thái). The word 'khŏ' (ขอ) is placed close to the word 'yo' (ยอ), which shares the same vowel sound. Moreover, the word 'yo' also shares the same consonant sound with the word following , 'yót' (ยศ). The other one is called 'sămphàt khân' (สัมผัสคั่น) -separated rhymes because poets insert one, or more than one word to separate words which share the same vowel or consonant sounds. An illustration of separate rhymes can be seen in 'ขินดีเหลือ ที่อ้าง' (yin di lǔea thî âng). The word 'di' (ดี) rhymes with 'tĥ̂' (ที่) and they are 
separated by the word 'lǔea' (เหลือ). However, it is not common practice to put a lot of words in between because it makes the sounds of repeated vowels or consonants seem far apart and thereby an indistinct internal rhyme results.

The researcher has found that in composing khlong, poets have followed the tradition of using internal rhyme of both consonants and vowels to enhance the melodious quality of khlong as follows:

Alliteration is the repetition of the initial consonant but different vowels and succeeding consonants in each stanza. Alliteration is dominant in the Thai language as can be seen in the employment of doublet in words such as 'rûatreo' (รวดเร็ว), 'thonthan' (ทนทาน), 'yókyông' (ขกย่อง), 'chomchoei' (ชมเชย) etc. Alliteration has been used in khlong by poets for a long time. This can be seen from the fact that every khlong written at the beginning of the Ayudhaya period used alliteration until it became a traditional belief that alliteration was the dominant key to make khlong melodious.

There are various forms of alliteration such as placing words which share the same consonant sounds close together or words which share only the same initial consonant sounds throughout the whole stanza, alliteration of the words between the first and last hemistiches of each line (One line consists of two hemistiches; thus, it is a play on the consonant sounds of different hemistichs), alliteration of the words in the last hemistich, which consists of only two words.

A good example can be seen in one of the khlong in Yuan Phai Khlong Dan, where it is replete with different kinds of alliteration, such as alliteration of two consecutive words, alliteration of the words of different hemistiches and alliteration in the last hemistich of each line:

thúk hŏ thúk hàeng mán lót khùean lót khǔa khanăn chông cháng mù lǔang tháng pàk tháng puang phon hăen hàe pàk khwàk pen khwăeng khwâng thŭa thang

\section{(Wannakam Samai Ayudhaya}

$$
\text { Vol.I, 1997: 332) }
$$

Alliteration has been continuously employed in khlong, even in modern khlong. Some poets have practised it until it has become their noticeable style as Cholada Ruengruglikit suggests in claiming that Sunthon Phu liked to compose Khlongsisuphap which plays on alliteration across the hemistich of each line for the entire 4-line stanza, so much so that we can say that it is his unique style. (Cholada Ruengruglikit. 2004: 964-989). Additionally, Supreme Patriarch Prince Paramanuchitchinorot is another poet who liked to use alliteration across the hemistich.

In the modern period, the poets who have followed the tradition of using alliteration across the hemistich are Naowarat Phongphaibun and Phaiwarin Khao-ngam. Both of them preserve the traditional belief in using internal rhymes to enhance the melodious quality of khlong as can be seen in their practice of alliteration in their khlong.

Rhymes are another distinctive feature in the Thai language. In spoken language, we can find that Thais tend to use words which have rhymes. In composing khlong, poets use rhymes to create beauty in their khlong. Rhymes were also found in khlong 
written at the beginning of the Ayudhaya period, though they were not as popular as alliteration. However, there was no requirement as regards the exact position of rhymes.

The researcher has found that rhymes which were applied with every single line in an entire 4-line khlong can be seen in some khlong of this period as testified by the rhymes used in the first hemistiches of the 4-line stanza in Yuan Phai Khlong Dan:

(1) (2) (3) (4) (5) (6) (7)

hăng făng lăng dêng sìap kho khang

(1) (2) (3) (4) (5) (6) (7)

lio lâen phlan nàk chák ngâi lám

(1) (2) (3) (4) (5) (6) (7) (8) (9)

phi sŏng nông kang hăng chan chòp kon hae

(1) (2) (3) (4) (5) (6) (7)

tin trìap khô kho ngám ngông ngam

(Wannakam Samai Ayudhaya

Vol.I, 1997: 345)

The practice of using rhymes in a systematic way was developed in the mid and late Ayudhaya period, when Khlongsisuphap became popular. The most prevailing style of rhyme use in these two generations was like that in Yuan Phai Khlong Dan, that is, rhymes were used in the first hemistich of each four lines but there was a more restricted rule about the exact position of rhyming than that at the beginning of the Ayudhaya period.

Phrasimahosot's Kaphorkhlong best illustrates the use of rhymes in the second and third words in the first hemistich of each line, in nearly every stanza:

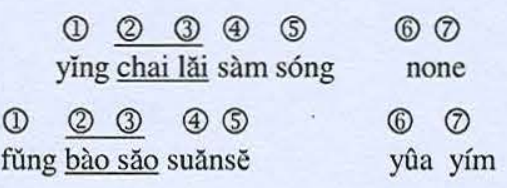

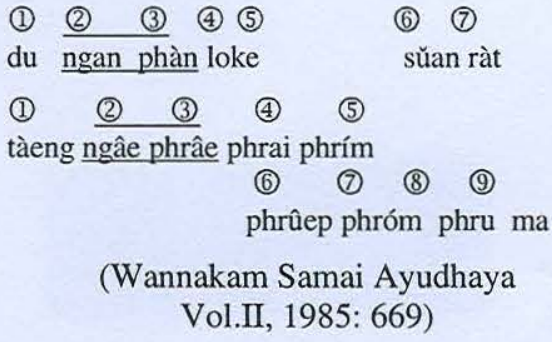

Like alliteration, rhymes may be found in words which are either put close together or separated by a word or words. However, it is found that poets tended to use rhymes of neighbouring words because this yields a continuous rhyming effect. The positions where rhymes occurred were varied. They can be found in the middle of the first hemistich, at the end of the first hemistich and at the beginning of the last hemistich of the same line, at the end of a line and two additional words, which are allowed to be added at the end of lines one and three, according to the rules of determining the number of words, and in the middle of the last hemistich of line four of Khlong-sisuphap.

Poets of the Rattanakosin era have been endowed with the traditional use of rhymes. The purpose of rhyme employment is for the sake of melody as can be seen in Lilit Taleng Phai. Sunthon $\mathrm{Phu}$ is considered a poet who was so consistent with definite positions of rhyming. Poets of later generations considered the rhyming positions used by Sunthon Phu a rhyming system. In his Khlongnirat Suphan, he rhymed the second word with the third word in the first hemistich regularly, so it turned out to be his unique style. Moreover, Sunthon Phu also rhymes the last word with additional words in line three, as well as rhyming the words in the last hemistich of line four. 
Later, some poems which show the tradition of rhyming, especially rhyming of the words in the middle of the first hemistich and of the last hemistich of the last line in Khlongsisuphap can be found in Prince Narathippraphanphong's Rubiyat and Prince Phitthayalongkorn-No Mo So's Sam Krung. Even though the rhyming systems in these two works were not as obvious as those found in Sunthon Phu, rhymes were used regularly in almost the entire khlong, mostly in the middle of the first hemistich of the 4 lines.

Rhymes can be seen in modern khlong as well. Lots of poets, such as Angkhan Kanlayanaphong, Naowarat Phongphaibun and Phaiwarin Khao-ngam use rhymes in their poems in the same way as poets did in the Ayudhaya period and at the beginning of the Rattanakosin era.

Modern poets not only preserve the tradition of using rhymes but have also adapted it. This seems to be considered novel and creative but in fact it is based on the concept of playing on rhymes which has been passed on from one generation to another. Phaiwarin Khao-ngam's Ming Khwan Klon, a two-stanza khlong which was composed in the form of Khlongsisuphap compiled in a book of khlong titled Chao Nok Kawi, can serve as a good example to illustrate this process. The poet makes use of rhymes not only between the words in the first hemistich of every line but also across the hemistiches too. This technique is considered unique since it had never been used by any poets before.

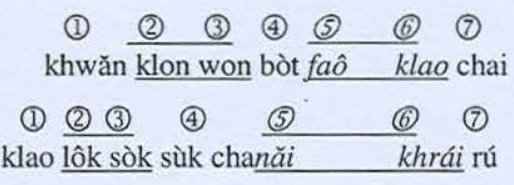

$$
\begin{aligned}
& \text { (1) (2) (3) (4) (5) (6) (7) } \\
& \text { kon klon kòn kan klai nai adit } \\
& \text { (1) (2) (3) (4) (5) } \\
& \text { khwăn klòm lơm bòt } \underline{s \hat{u}} \\
& \begin{array}{l}
\text { (6) (7) } \\
\text { sù buêang pàtchuban }
\end{array}
\end{aligned}
$$

(Phaiwarin Khao-ngam, 1998: 34)

All in all, internal rhymes can be regarded as a technique to help create a melodious quality in khlong. From the data gathered by the researcher, it can be found that rhymes are no less important than alliteration. Poets have developed the style of using rhymes, starting with the rare use in early Ayudhaya khlong, the systematic rhyme order as seen in the first hemistich of middle Ayudhaya khlong, the obvious rhyme system created by Rattanakosin poets, and the experiments of modern poets in putting rhymes in various orders and more places in khlong than was practised in ancient khlong.

\section{Conventions and Creative Aesthetics of Khlong in Regard to Diction}

Another important aspect of the creative aesthetics of khlong is diction. The use of diction can be classified into two main types: puns and repeated words.

\section{Puns}

Puns refer to either homonyms or homophones. Due to the fact that words in the Thai language are monosyllables which do not change their form in terms of grammatical rules like other languages and that some words are spelled and pronounced the same but give different meanings, the context and the position of the word are required to gain the right 
meaning of the word. Poets make use of this feature in playing with the sound and meaning of khlong. It can be seen that puns have been prevalent in khlong of all eras from Ayudhaya to the present day

It can be said that the use of puns, especially homonyms, characterizes the traditional style of writing Nirat. Using homonyms, poets can express more of their feelings and message, especially melancholy when apart from their beloved. Therefore, we find that in composing Nirat since the Ayudhaya period, poets have used puns as their technique, as testified by the fact that puns can be found in every Ayudhaya Nirat. Some good examples are Kamsuan Khlong Dan, Lilit Phra Lo, Kaphorkhlong Nirat Than Sok, and Kaphorkhlong Nirat Than Thongdaeng.

In composing Nirat in the Rattanakosin era, poets preserved the traditional use of puns by Ayudhaya poets as can be seen in an excerpt from Khlongnirat Narin:

\begin{tabular}{ll}
\multicolumn{1}{c}{ nang nuan chàp mâek mái } & nang nuan \\
nuannút nâep riam khuan & khû khláeo \\
benchawan chàp wan phuan & phan òp mái mâe \\
lae wâ wan kon kâeo & kòt ôm eowan
\end{tabular}

(Kap He Rua, Kap He Rua Chiwit, Nirat Narin, 1967: 147)

It can be seen that homonyms used in the above excerpt give different meanings. They can be a kind of bird, a plant or the poet's beloved. To clarify, the word 'nuan' (นวล) in 'nangnuan' (นางนวล) can be both a sea gull or a kind of tree and in 'nuannút' (นวลนุช) refers to a beloved maiden. Another type of pun, homophones, is also used as seen in the word 'wan' (วร5ณ) in 'benchawan' (เบญจวรรณ) a kind of bird. Then the poet describes how this bird flies to perch on 'wan' (วัลย์) a creeper, and then he links this image to his beloved by using the word 'eowan' (เอววัลย์) in the sense of a woman. The style of using puns as found in this khlong can also be seen in Lilit Phra Lo, at the beginning of Ayudhaya literature.

In modern poetry, puns can be found not only in Nirat, but also in khlong with different subject matter such as commentary on human life and society. Naowarat Phongphaibun's Chak Ma Chom Mueang is a good example. In this long poem, the poet plays on the word 'sàt' which yields many different meanings.

\begin{tabular}{|c|c|}
\hline สัตว์เจอสัตย์สัตว์แจ้ง & สัจจา \\
\hline สัตว์สบอสัตข์สัตว์สา & สัตว์ร้าย \\
\hline สัตว์ทรงสัตย์ศรัทธา & ธรรมสัจ \\
\hline สัตย์สู่สัตว์อสัตย์พ่าย & ผ่องสร้างสัจธรรม \\
\hline
\end{tabular}

(Naowarat Phongphaibun, 1977: 39)

sàt choe sàt sàt châeng sàt cha

sàt sòp àsàt sàt să sàt rái

sàt song sàt sàttha thammasàt

sàt sù sàt àsàt phâi phòng sâng sàtchàtham

The poet enhances the meaning of the poem by using puns effectively. His collection of words which share the same sound but have different meanings can be seen in the word 'sàt' with its different spellings - สัตว์, สัตช์, อสัตช์, สัจจา, สัจธรรม, ศรัทธา. The idea that the poet wants to convey is that faithfulness 'sàt' (สัตช์), which is considered a virtue, can help mankind 'sàt' (สัตว́), regarded as another type of animal in the context, have a profound understanding of truth 'sàtchàtham' (สัจธรรม). If man is still trapped in the loop of evil 'àsàt' (อสัต์์), he is no different from other kinds of animals 'sàt' (สัตว์). Thus, man should have faith in 
truth 'sàttha' (ศรัทฐา) and he will be able to defeat evil and understand truth.

It can be said that the use of puns, both homonyms and homophones, is popular among poets of all eras, and thus it has become like a literary treasure which has been passed down from one generation to another.

\section{Repeated Words}

Repeated words here refer to the employment of the same word more than once. Using repeated words, poets not only play on the sound of the repeated word but also emphasize the meaning of the word. Repeated words can be found in every type of khlong from the early Ayudhaya period to the modern poetry of the present day.

The use of repeated words not only shows that poets of a later generation preserve the tradition of composing khlong from the previous generation but also reflects the creativity and taste of poets in each era as can be seen from their attempts to put repeated words in different positions in khlong. The technique of placing repeated words in khlong varies. Repeated words may not be assigned any specific place in khlong, or they may occur in the same line, either being placed close together or separated by some words, across the hemistich in the same line, at the beginning of the hemistich or line, between lines by repeating the words at the end of the previous line, at the beginning of the next line, and at the beginning of each stanza. Repeated words can be either one word, one group of words, one hemistich, or one line but what is found most commonly is the use of one repeated words and one group of word rather than a repeated hemistich or line.
In Lilit Phra Lo, epanalepsis, repeated words which are separated by some words, is used in both Khlongsisuphap and Khlongsongsuphap. Especially in Khlongsongsuphap, poets separate repeated words with a word as exemplified below:

săo sanŏm chon kàen thái

hâi chè̀ hâi sàephâi luêat nám ta lăi lae na

(Wannakam Samai Ayudhaya Vol.I, 1997: 488)

In this Khlongsongsuphap, the poet repeats the word 'hâi' ("ห้) three times separately. This is to emphasize the gestures and feelings of sadness of the character. The use of repeated words which are separated by some words can be seen in the work of poets of later generations as well. In King Rama V's Lilit Nitthra Chakhrit, the poet not only uses repeated words which are separated by some words in the same hemistich, but also across the hemistich.

phlôt bo chang chûet thôi

thân phlôt khăo phlôt phlôi phlôt tô ('ต้) tò (ต่อ) sanǒng

(King Rama V, 1995: 10)

In this khlong, the poet repeats the word 'phlôt' (พลอด) to emphasize the fact that the character keeps repeating the same action without realizing it. Cholada Ruengruglikit makes an interesting note on the use of repeated words separated by some words in this khlong when she points out that the positions of the repeated words in the poem are in exactly the same places in Lilit Phra Lo, that is in the last hemistich. Also, the poet uses repeated words in the first hemistich of Khlongsongsuphap, which is considered a development in the use of repeated words. 


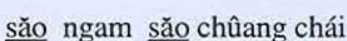

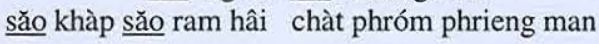

(Cholada Ruengruglikit. 2005: 89)

Besides being used in Khlongsongsuphap, repeated words are found in every type of khlong of the Ayudhaya period, too. The researcher has found that the technique of using repeated words separated by some words prevails in each hemistich as seen in Yuan Phai Khlong Dan. It can be found that the repeated words were assigned specific places in every first hemistich similar to the characteristics of composing Khlongkonlabot as shown below:

$\begin{array}{ll}\text { phrá khun phrá khrôp fâ } & \text { din khăm } \\ \text { phrá kàit phrá krai phăn } & \text { phàn fá } \\ \text { phrá rít phâng phrá ram } & \text { ron râp sâi hae } \\ \text { phrá kò phrá kûea lâ } & \text { làk sawăn }\end{array}$

(Wannakam Samai Ayudhaya Vol.I, 1997: 341)

The use of epanalepsis can be seen in several of Rattanakosin khlong. The words may be repeated twice as seen in 'yôk sûeng năm ao năm sàe sîan' (Khlongnirat Phraya Trang) or three times as seen in 'rák châi rák ram rák sùt rú' (Khlongnirat Narin).

In modern khlong, the use of epanalepsis is still practised by poets as can be seen in the following excerpt from Naowarat Phongphaibun's Athit Thueng Chan:

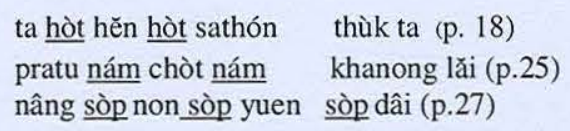

Another type of repeated word is the repetition of 'kham tho' (คำโท), a word which has a falling tone mark, in the fourth line of Khlongsisuphap. This yields not only melodious but meaningful effects in the khlong. The fifth word of the first hemistich is repeated in the second word of the last hemistich. This position is the required place for 'kham tho'; thus the researcher will call this kind of repeated word 'repeated 'kham tho' in the fourth line'. This kind of repeated word was used since the early Ayudhaya period as can be seen in Lilit Phra Lo, in which the poet employed this technique in a lot of stanzas until it became a distinctive feature of this work as shown below:

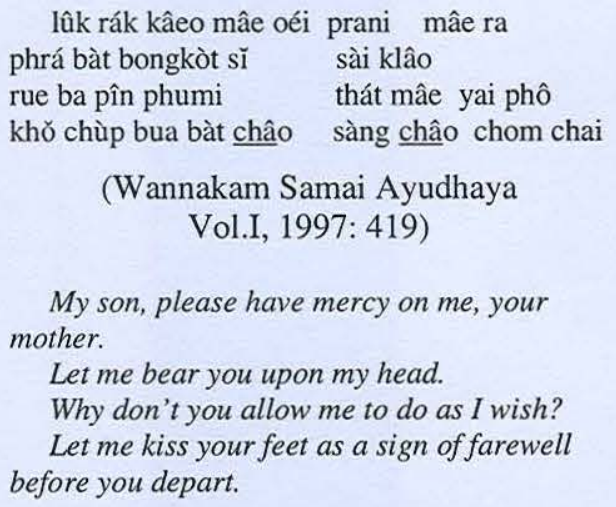

Let me bear you upon my head.

Why don't you allow me to do as I wish?

Let me kiss your feet as a sign of farewell before you depart.

Later, repeated 'kham tho' in the last line of Khlongsisuphap became popular in composing Khlongnirat such as Khlongnirat Chaofa Aphai and Khlongnirat Phraphutthabat near the end of the Ayudhaya period and Khlongnirat Phraya Trang, Khlongnirat Phraprathom, and Khlongnirat Narin in the early Rattanakosin period. In modern khlong, the researcher has found that poets also preserve the tradition of repeating 'kham tho' in the fourth line of Khlongsisuphap as can be seen in the works of Naowarat Phongphaibun and Phaiwarin Khao-ngam.

The repetition in 'kham tho' in the last line of Khlongsisuphap makes it more melodious. Also, the last line is considered most important in terms of meaning because it sums up the concept of the khlong. Thus, the use of repeated words 
helps make the message of the khlong obvious.

Another common technique of repeated words is anaphora, repeated words at the beginning of a line. This is mostly found in early Ayudhaya khlong such as Yuan Phai Khlong Dan, Kamsaun Khlong Dan, and Lilit Phra Lo. The use of anaphora can be found either in some lines or in every line of the four line stanza. This technique has been preserved in composing all types of khlong, especially Nirat and didactic khlong. The use of repeated words at the beginning of a line assists not only in creating a melodious effect, and emphasizing the concept of the khlong like other types of repeated words, but also in classifying and organizing the ideas, resulting in clear presentation of the message. Thus, it is mostly found in didactic khlong as in Khlong Lokkanit:

wén wíchan wâng wén sadàp fang wén thî thăm an yang pài rú wén lâo likhìt sang- kèt wâng wén na wén dang klào wâ phû pràt dâi rue mi

(Prachum Khlong Lokkanit,1996: 118)

The word 'wén' (เว้น) which means refrain is used at the beginning of four lines to emphasize that restraint from criticizing, asking and writing is not in the nature of the sage. It can be seen that the repetitive 'wén' helps classify and organize the ideas of the khlong and accentuates the lessons that the poet would like to teach.

From the aforementioned discussion on homophones and repeated words, the researcher has found that they are the most distinctive literary technique in composing all types of khlong in Thai literature. They create aesthetics in both sound and meaning. Even though this technique is also used in other kinds of poems, it becomes more varied when it is applied to khlong; moreover, the position where it is employed also yields different literary effect. Thus, it is clear why poets of all eras have followed the technique of employing repeated words to create homophones and puns in different places in khlong because it gives beauty to khlong in regard to sound and meaning.

\section{Conventions and Creative Aesthetics of Khlong in Regard to the Imitation of Words Used by Previous Poets with New Meaning}

As mentioned earlier, poets use puns and repeated words to create effects in melody and meaning at the level of words, especially Khlongnirat whose pattern encourages a play on words and sounds which suitably convey the feelings of poets towards their beloved. This resulted in the popularity of homophones and homonyms in composing Nirat in the earlier period and in becoming accepted as a model for poets of later generations to follow. However, there will not be any advance in composing khlong if poets only imitate the style of poets of previous generations; thus, poets have to look for novel ways of writing to guarantee that their poems do not lack aesthetics in terms of 'the concept of the khlong'.

To prevent such repetition, poets avoid using a fixed form of employing puns in khlong by conveying new dimensions of meaning which are different. Poets try to assert their individuality in khlong to create a 'new concept' as can be illustrated by Khlongnirat in Sam Krung. The poet tries to create an extraordinary meaning from using puns and asserts his uniqueness by the use of puns. It can be seen that even though the technique of using homophones and homonyms of the birds and plants as 
seen in Khlongnirat of the earlier period is still used, the poet uses the technique in a new idiomatic expression:

$\begin{array}{ll}\text { salàtdai salàt dûai hèt } & \text { dang rue } \\ \text { hěn chà năm tam mue } & \text { mâen láeo } \\ \text { salàt dai châi uèn khue } & \text { salàt hàt } \\ \text { thùk rue àt khlât khláeo } & \text { mâi rú tu dao }\end{array}$

(Prince Phitthayalongkorn, 1973:35)

Seeing the Salatdai tree makes me wonder why we have to 'flick away our hand'.

I guess it might be because our hand has been pricked by a thorn, hand'.

Since Salatdai means 'flicking away one's

I do not know whether my guess is correct, but that is what I reckon.

The idiomatic expression, 'sàlàtdai' (สลัดได) and 'sàlàt dai' (สลัด ได) in the above khlong was used in Khlongnirat of the earlier period, Lilit Taleng Phai. The pun 'sàlàtdai' refers to a tree which is associated with the poet's beloved as shown below:

salàtdai dai salàt nóng năeng non phrai rue phró phuêa ma ran ron sòek sâi salà salà samŏn samǒe chue mái na núek ràkam nam mái mân mán suang riam

(Supreme Patriarch Prince Paramanuchitchinorot, 1987: 25)

Seeing the Salatdai tree makes me wonder why I have to leave you, my beloved, and lie alone in this wood,

This is because I have to go to war,

Upon seeing the tree called Sala whose name means 'abandon', I can't help thinking of my desertion of you,

And when I behold the tree called Rakam its name reminds me of the agony in my mind.

In Lilit Taleng Phai, the poet made use of a homophone in 'sàlàtdai' (สลัดได) which is a kind of tree by switching the order of the word to 'dai sàlàt' (ใดสลัด). The word 'sàlàt' here means 'leaving' or 'flicking away' and the word 'dai' (ใด) whose spelling is different from 'ได' but shares the same sound denotes a question. This results in a change of meaning from a kind of tree to a form of question. Rearranging the order of words makes use of the distinctive nature of the Thai language, that is, the meaning of the message is changed in correspondence with the order of the words. The use of a question in this khlong emphasizes the sadness of the character in the poem. In Sam Krung, the poet also uses the same word 'sàlàtdai' but he separates it into two word units. The verb 'sàlàt' shows movement and the word 'dai' is a borrowed word from Khmer, meaning 'hand'. Therefore, though the same word is used, the poet in Sam Krung does not talk about his beloved as the poet of Lilit Taleng Phai does. It can be seen that the poet imitates the expression used in ancient khlong but adapts it to suit his own needs-creating humour in the khlong.

An imitation of puns from khlong of previous periods can also be found in modern poetry. For instance, in one Khlongnirat, the poet imitates the use of the word 'săiyùt' (สายหยุด) in Lilit Taleng Phai. He plays with the meanings of this word at the level of morphology. As a compound noun, 'săiyùt' is the name of a flower but if it is separated into two units 'săi' and 'yùt' we will get new meanings as the word 'săi' means 'late morning' and the word 'yùt' is a verb which means 'stop'. The poet uses it to describe the never-ending love that the Crown Prince (Phra Maha Upparacha) has for his beloved. The play on the form and structure of words is used in various concepts apart from love by a lot of poets 
in modern poetry. For instance, Angkhan Kanlayanaphong uses it to convey the meaning of life philosophical. Komthuan Khanthanu uses it in a political sense, portraying the people's demonstration for democracy in October, 1973. Thus, it can be seen that even though poets imitate the words used in ancient khlong, they adapt them to suit the concept of the khlong and at the same time assert their individuality by using them in their own unique way.

\section{Conclusion}

It can be seen that in composing khlong, poets of every era make use of the distinctive nature of the Thai language to create aesthetics of khlong in such different aspects as euphony as seen in the play on different tone levels and internal rhymes, in diction as illustrated in the use of puns and repeated words and in semantics by adapting the same words or expressions employed by poets of previous generations. In adopting and creating new styles of writing, poets not only preserve the tradition of composing khlong but also develop it to suit their purposes and assert their individuality.

However, the way to create and appreciate khlong at present has changed in accordance with the development of the literary world. Khlong, which once used to be written for the sake of melody, is now written for other ends such as criticism of society or commentary on contemporary problems. It can be seen that poets put more emphasis on the ideas. However, this does not mean that modern poets have deserted the conventions of khlong composition as we can see that some modern poets still study and follow the beautiful and valuable traditional style of writing khlong which makes use of the distinctive nature of the Thai language because it yields literary aesthetics. Therefore, it is not surprising to see the idea of aesthetics in khlong has been passed on from one generation to another and become part of the literary conventions in modern Thai poetry.

\section{References}

Angkhan Kanlayanaphong. 2003. Panithan Kawi. $8^{\text {th }}$ edition. Bangkok: Siam.

Chit Phummisak. 1981. Ongkan Chaeng Nam Lae Kho Khit Mai Nai Prawattisat Thai Lum Nam Chao Phraya. Bangkok: Duangkamon.

Chiwit Lae Ngan Khong Sunthon Phu. 1987. $13^{\text {th }}$ Edition. Bangkok: Khurusapha.

Cholada Ruengruglikit. 2001. Wannakhadi Samai Ayudhaya Ton Ton: Laksana Ruam Lae Itthiphon. Bangkok: Faculty of Arts, Chulalongkorn University.

Cholada Ruengruglikit. 2003. Wannalalit Ruam Botkwam Wichai Wannakhadi Lae Khampraphan Thai. Bangkok: Faculty of Arts, Chulalongkorn University.

Cholada Ruengruglikit. 2004. Khlong Patterns of Sunthon Phu and Their Origin. Journal of the Royal Institute of Thailand 29.4: 964989.

\section{Cholada Ruengruglikit. 2005. Wannawichai Ruam Botkhwam Wichai Wannakhadi Ayudhaya Lae Rattanakosin Bang Rueang. Bangkok: Faculty of Arts, Chulalongkorn University.}


Kap He Ruea, Kap He Ruea Chiwit, Nirat Narin. 1967. Bangkok: (n.p.)

Komthaun Khanthanu. Nattakam Bon LanKhwang. (n.y.) $8^{\text {th }}$ editon. Bangkok: Mingmit

Narathippraphanphong, Prince. 1973. Rubaiyat. Bangkok: Bannakhan.

Narathipphongpraphan, Prince. 1975. Kho Khit Kiao Kap Phasa Lae Wannakhadi. Bangkok: Thai Studies Institution, Thammasat University.

Naowarat Phongphaibun. 1974. Athit Thueng Chan. Bangkok: Phikkhanet.

Naowarat Phongphaibun. 1977. Chak Ma Chom Mueang. Bangkok: Karawek.

Paramanuchitchinorot, Supreme Patriarch Prince. 1987. Lilit Taleng Phai. $2^{\text {nd }}$ edition. Bangkok: Ongkankha Khong Khurusapha.

Prakhong Nimmanhaeminda. 1987. The Thao Ba Chueang Epic: An Analytical Study. Ph.D. Dissertation. Graduate School, Chulalongkorn University.

Prachum Khlong Lokkanit. 1996. 30 edition. Bangkok:

Ratbandittayasapha.

Phathani Chotikkasathian. 2001. Siang Nai Phasa Thai. In Eakasan Kan Son Chut Wicha Phasa Thai Sam. Nonthaburi: Sukhothaithammathirat University.
Phitthayalongkorn, Prince. 1973. Sam Krung. Bangkok: Bamrungsarn.

Phaiwarin Khao-ngam. 1998. Chao Nok Kawi. Bangkok: Phraeo Publishing.

Rama V, King. 1995. Lilit Nitthra Chakhrit. Bangkok: Bannakit Trading.

Uppakit Sinlapasan, Phraya. 1992. Lak Phasa Thai. Bangkok: Thai Watthana Phanit.

Wannakam Phraya Trang. 1972. Bangkok: Bannakhan.

Wannakam Samai Ayudhaya Vol.I. 1997. $2^{\text {nd }}$ edition. Bangkok: Krom Sinlapakon.

Wannakam Samai Ayudhaya Vol.II. 1985. Bangkok: Krom Sinlapakon.

Watchari Ramayanun. 1995. Wiwatthanakan Roi Krong Thai.Bangkok: Chulalongkorn University Press. 